\title{
Rootstock affects the blend of biogenic volatile organic compounds emitted by 'Hass' avocado
}

\author{
Ricardo Ceballos ${ }^{1}$, and Tommy Rioja ${ }^{2,3^{*}}$ \\ 'Instituto de Investigaciones Agropecuarias, INIA Quilamapu, Av. Vicente Méndez 515, Chillán, Chile. \\ ${ }^{2}$ Universidad Arturo Prat, Facultad de Recursos Naturales Renovables, Campus Huayquique Av. Arturo Prat s/n, Iquique, Chile. \\ "Corresponding author (trioja@unap.cl). \\ ${ }^{3}$ Universidad de Tarapacá, Facultad de Ciencias Agronómicas, Campus Azapa km 12, Arica, Chile.
}

Received: 5 November 2018; Accepted: 12 February 2019; doi:10.4067/S0718-58392019000200330

\begin{abstract}
Grafting, using tolerant rootstocks, has been necessary to increase avocado (Persea americana Mill.) production in drought, salinity, pest, and soil disease conditions. The avocado rootstock has shown an influence on scion vigor, nutrient absorption, fruit quality, and disease tolerance. Nevertheless, the avocado rootstock influence on the biogenic volatile organic compounds (BVOCs) emitted from 'Hass' shoots has not been reported. Our objective was to study the effect of two avocado rootstocks of the Mexican race on BVOC emitted by avocado 'Hass' shoots. We collected BVOCs emitted by 'Hass' avocado shoots grafted on 'Mexicola' and 'Zutano' rootstocks. All volatile collections were made from living plants for $24 \mathrm{~h}$ through a dynamic headspace technique. The chemical profiles were analyzed by gas chromatography coupled to a mass spectrometry (GC-MS). BVOC emission rates were highly variable in amount and composition. The monoterpene $\alpha$-pinene was emitted at $5.06 \pm 0.74,0.73 \pm 0.14$, and $1.43 \pm 0.61 \mu \mathrm{g} \mathrm{mL} \mathrm{m}^{-1}$ by graft 'Hass'/'Mexicola', 'Hass'/'Zutano' and ungrafted 'Mexicola', respectively. Grafted 'Hass' on 'Mexicola' emitted a wide variety of monoterpenes as $\beta$-pinene, cumene, 3-carene, $R$-limonene and ( $Z$ )- $\beta$-ocimene, whereas grafted plants on 'Zutano' only released $\alpha$-pinene and cumene. Estragole was only detected on ungrafted 'Mexicola'. We found that the chemical profile of volatile compounds released by 'Hass' grafted avocado plants was qualitatively and quantitatively influenced by rootstocks.
\end{abstract}

Key words: Avocado, headspace collection, Persea americana, plant volatiles, rootstock.

\section{INTRODUCTION}

Modern agricultural practice of grafting vegetal material and rootstock use has allowed cultivating in unfavorable conditions such as extreme temperatures, drought, salinity and flooding (Colla et al., 2010; Schwarz et al., 2010; Reeksting et al., 2014). Resistant and/or tolerant rootstocks to insect pests and pathogens increase the production, scion vigor, and organoleptic fruit quality (Warschefsky et al., 2016).

Structural, biochemical and genetic factors influence the grafting process (Martínez-Ballesta et al., 2010). The scionrootstock union and callus development produce molecular changes that affect scions' defense mechanisms (Cookson et al., 2013; Trinchera et al., 2013; Lordan et al., 2017). On the other hand, the transport of RNA, DNA, phyto-hormones and proteins between scion and rootstock elicit phenotypic changes on grafted plants (Wang et al., 2016).

Secondary metabolites such as alkaloids, non-protein amino acids, amines, cyanogenic glycosides, glucosinolates, terpenoids, and phenolics are constitutively produced by plants (Jamwal et al., 2018; Moreno-Medina et al., 2018). Biogenic volatile organic compounds (BVOC) are emitted through intercellular spaces, whereas stomas release them into the environment (Kegge and Pierik, 2010). As a result, terpenoids, aldehydes, green leaf volatiles (GLV), indole, and aromatic compounds are released (Loreto et al., 2014). These compounds have important physiological functions, 
and direct and indirect defensive roles (Sabelis et al., 2011; Mithöfer and Boland, 2012). BVOC are chemical cues for the attraction or repellence of phytophagous insects and plant pathogens, providing key information on host-plant status (Ueda et al., 2012; Holopainen and Blande, 2013; Lu et al., 2015). Herbivore-induced plant volatiles (HIPVs) are emitted after herbivory (Arimura et al., 2011; Gols, 2014; Heil, 2014); thus, specific odor cues are exploited by predators and parasitoids. In addition, HIPVs are modified by arthropod species, herbivores density, genotypes and plant cultivars, plant ontogeny, and abiotic factors (Hare, 2010; Hare and Sun, 2011; Proffit et al., 2011; Becker et al., 2015; Clavijo, 2016; Rioja et al., 2016).

Avocado 'Hass' emits mainly GLV, alkane and monoterpene compounds (Bravo-Monzón and Espinosa-García, 2008; Rioja et al., 2016; 2018). Rincón-Hernández et al. (2011) described differences in the chemical profile of volatiles compounds on Guatemalan, Mexican and West Indian race. García-Rodríguez et al. (2016) found variability in the emitted compounds by 'Hass' trees propagated clonally. Most investigations have focused on mineral transportation rootstock effect, defense-gene expression, hormone production and abiotic stress tolerance. We studied the effect of two avocado rootstocks of the Mexican race on BVOC emitted by avocado 'Hass' -shoots.

\section{MATERIALS AND METHODS}

\section{Plants and BVOC collections}

'Hass' avocado scions were grafted on two Mexican race rootstocks, 'Mexicola' and 'Zutano', and cultivated in 7 L containers filled with organic soil and peat. The plants were fertilized (Ultrasol 18-18-18, Soquimich, Santiago, Chile) and irrigated suitably. We included a set of 'Mexicola' ungrafted plants, cultivated as described above. The volatile collections were carried out during summer season, under semi-field conditions using a greenhouse $(3 \mathrm{~m} \times 2.5 \mathrm{~m} \times 4 \mathrm{~m})$, in Instituto de Investigaciones Agropecuarias INIA La Cruz (3249’ S; 71¹7’ W), Quillota, Región de Valparaíso, Chile.

For all in situ collections, we used 2-yr-old plants and a dynamic headspace technique with a positive/negative air system. We carefully enclosed a healthy and undamaged branch in a polyethylene terephthalate (PET) bottle $(1.5 \mathrm{~L})$ divided into halves along. The parts were secured with Teflon tape to avoid mechanical damage to leaves. A purified airstream (charcoal 8-20 mesh, Sigma-Aldrich, St. Louis, Missouri, USA) was pumped into the PET bottle at $1000 \mathrm{~mL}$

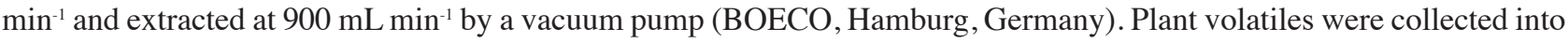
chemical traps (13 cm in length and $5 \mathrm{~mm}$ in internal diameter) filled with $100 \mathrm{mg}$ Porapak Q (80-100 mesh, Supelco, Bellefonte, Pennsylvania, USA) inserted into an upper outlet of the bottle. Traps were previously cleaned with $1 \mathrm{~mL}$ diethyl ether and conditioned for $2 \mathrm{~h}$ at $220{ }^{\circ} \mathrm{C}$ under a constant stream of $40 \mathrm{~mL} \mathrm{~min}{ }^{-1}$ of nitrogen (Ceballos et al., 2015). After $24 \mathrm{~h}$ of collection, we eluted the volatiles from Porapak using $1 \mathrm{~mL}$ hexane (95\%, Sigma-Aldrich).

\section{Chemical analysis of BVOC by GC-MS}

An aliquot of $1 \mu \mathrm{L}$ of the eluted samples was injected into a gas chromatographer coupled to a mass spectrometer (GCMS; QP2010 Ultra, Shimadzu, Kyoto, Japan), equipped with an RTx 5 capillary column (30 m, $0.25 \mathrm{~mm}$ ID, $0.25 \mu \mathrm{m}$ film thickness; Restek, Bellefonte, Pennsylvania, USA). The injection mode was split-less, and helium was used as the carrier gas with a constant flow at $1.0 \mathrm{~mL} \mathrm{~min}{ }^{-1}$. The GC oven was programmed at $40{ }^{\circ} \mathrm{C}$ for $2 \mathrm{~min}$ and then increased at a rate of $5{ }^{\circ} \mathrm{C} \mathrm{min}{ }^{-1}$ until $225^{\circ} \mathrm{C}$. The acquisition was carried out in the mass range from 50 to $500 \mathrm{~m} / \mathrm{z}$, whereas the ionization was performed by an electron impact at $70 \mathrm{eV}$ with an ion source at $230^{\circ} \mathrm{C}$. The BVOC identity was verified by comparing their retention times while mass spectrum was corroborated with a library database (NIST version 2.0, Standard Reference Data; National Institute of Standards and Technology [NIST], Gaithersburg, Maryland, USA). To quantify, a calibration curve was made with commercial standard of $\alpha$-pinene (Dr. Ehrenstorfer GmbH, Augsburg, Germany) under the same chromatographic conditions described above.

\section{Statistical analysis}

Six replicates were performed for volatile's entrainments and data from quantitative analysis of the emitted compounds were expressed as proportion of $\alpha$-pinene concentration in the corresponding plant condition. Data were analyzed by Student's $t$ test or ANOVA $(\mathrm{P}<0.05)$, according to its presence in two or three plants conditions, respectively. 


\section{RESULTS AND DISCUSSION}

The monoterpene $\alpha$-pinene was emitted at $5.06 \pm 0.74,0.73 \pm 0.14$, and $1.43 \pm 0.61 \mu \mathrm{g} \mathrm{mL} \mathrm{m}^{-1}(\mathrm{~F}=21.232 ; \mathrm{p}=0.001)$ by graft 'Hass'/'Mexicola', 'Hass'/'Zutano' and ungrafted 'Mexicola', respectively. These concentrations were employed to standardize the emissions of the other compounds on each plant condition. The graft 'Hass'/'Mexicola' emitted other monoterpenes as $\beta$-pinene, cumene, 3-carene, $R$-limonene and (Z)- $\beta$-ocimene, and 'Hass'/'Zutano' emitted cumene (Table 1). Rioja et al. (2016) collected BVOC from intact avocado 'Hass' grafted on 'Mexicola' registering the same compounds although in different concentrations. Bravo-Monzón and Espinosa-García (2008) found that 'Hass' avocado grafted on 'Criollo' rootstock released high abundance of $\alpha$-pinene, $\beta$-phellandrene, $\beta$-pinene, $\beta$-myrcene, $\alpha$-cubebene, $\alpha$-copaene, and $\beta$-caryophyllene. This may indicate that 'Hass' shoots are physiologically modified by the rootstock influence.

The graft 'Hass'/'Zutano' released high amounts of alkanes as 2,4 dimethyl-heptane ( $\mathrm{t}=2.358 ; \mathrm{p}=0.040), 3,7$ dimethyldecane $(\mathrm{t}=2.536 ; \mathrm{p}=0.029)$ and undecane, which were not detected in the volatile profiles emitted by 'Hass'/'Mexicola'. Graft 'Hass'/'Zutano' released a profile of BVOC conformed by $87.5 \%$ alkanes, $1.9 \%$ GLVs and $1.1 \%$ monoterpenes, unlike the graft 'Hass'/'Mexicola'. Rioja et al. (2016) registered low quantities of BVOCs emitted from 'Hass'-shoots grafted on 'Mexicola'. Furthermore, Bravo-Monzón and Espinosa-García (2008) did not register emissions of BVOCs from 'Hass'/“Criollo' combination. Seemingly, 'Zutano' increased volatile emissions from 'Hass' leaves.

An abundant emission of estragole was found only on ungrafted 'Mexicola' (Table 1). Bravo-Monzón and EspinosaGarcía (2008) registered that 'Criollo' plants, from the Mexican race just like 'Mexicola', emitted estragole at 54.75\% of abundance. Contrary to this, 'Hass' did not emit estragole because of its predominantly Guatemalan race. Moreover, Torres-Gurrola et al. (2011) collected high amounts of estragole from intact 'Criollo' leaves. Yet, Rioja et al. (2016) did not detect estragole emissions from 'Hass' shoots. Therefore, the estragole compound would be a characteristic of the

Table 1. Concentration of biogenic volatile organic compounds (mean $\pm \mathrm{SE}$ ) collected from grafted and ungrafted Persea americana 'Hass' for $24 \mathrm{~h}$.

\begin{tabular}{|c|c|c|c|}
\hline \multirow[b]{2}{*}{ Compound } & \multicolumn{2}{|c|}{ Grafted scion on rootstock } & \multirow{2}{*}{$\begin{array}{l}\text { Ungrafted } \\
\text { Mexicola }\end{array}$} \\
\hline & Mexicola & Zutano & \\
\hline & \multicolumn{3}{|c|}{ Proportion of $\alpha$-pinene concentration -} \\
\hline 3-Hexanone & $0.34 \pm 0.12 \mathrm{a}$ & $2.43 \pm 0.82 \mathrm{a}$ & $5.10 \pm 2.12 \mathrm{a}$ \\
\hline 2-Hexanone & $0.23 \pm 0.03$ & - & $1.69 \pm 0.56^{*}$ \\
\hline 3-Hexanol & $0.21 \pm 0.02 \mathrm{~b}$ & $2.01 \pm 0.67 \mathrm{ab}$ & $5.89 \pm 2.42 \mathrm{a}$ \\
\hline 3,4,5-Trimethyl-heptane & - & $3.15 \pm 1.06$ & - \\
\hline 2,4-Dimethyl-heptane & - & $57.83 \pm 19.54 *$ & $10.69 \pm 4.23$ \\
\hline 2,4-Dimethyl-1-heptane & $0.42 \pm 0.09$ & $9.69 \pm 3.34 *$ & - \\
\hline 2,3-Dimethyl-heptane & - & $1.58 \pm 0.48$ & - \\
\hline 4-Methyl-octane & - & $15.80 \pm 3.12 *$ & $5.60 \pm 2.27$ \\
\hline 2,3,4-Trimethyl-hexane & $0.11 \pm 0.03$ & $16.44 \pm 6.11^{*}$ & - \\
\hline$\alpha$-Pinene ${ }^{\dagger}$ & 1.00 & 1.00 & 1.00 \\
\hline$\beta$-Pinene & $0.56 \pm 0.14$ & - & $1.03 \pm 0.14 *$ \\
\hline Cumene & $0.06 \pm 0.01 \mathrm{~b}$ & $1.08 \pm 0.29 \mathrm{a}$ & $0.37 \pm 0.13 b$ \\
\hline 3-Carene & $0.45 \pm 0.04$ & - & - \\
\hline 4-Heptyn-2-ol & - & $1.56 \pm 0.41$ & $1.04 \pm 0.36$ \\
\hline$R$-Limonene & $0.90 \pm 0.32$ & - & - \\
\hline 2-Propyl-1-pentanol & $0.94 \pm 0.51$ & - & - \\
\hline$(Z)$ - $\beta$-ocimene & $0.59 \pm 0.17$ & - & - \\
\hline 3,7-Dimethyl-decane & - & $55.54 \pm 18.21^{*}$ & $8.79 \pm 2.86$ \\
\hline 6-Ethyl-2-methyloctane & $0.85 \pm 0.19$ & - & $6.82 \pm 2.59^{*}$ \\
\hline 3,3-Dimethyl-hexane & $0.38 \pm 0.03 \mathrm{~b}$ & $12.65 \pm 3.49 \mathrm{a}$ & $6.28 \pm 2.18 \mathrm{ab}$ \\
\hline 3-Ethyl-benzaldehyde & - & $5.54 \pm 3.14$ & $28.66 \pm 21.44 *$ \\
\hline Undecane & - & $28.88 \pm 8.14$ & - \\
\hline Estragole & - & - & $20.32 \pm 7.39$ \\
\hline$(2 E, 6 E)-4,5$-Dimethyl-2,6-octadiene & $0.74 \pm 0.17$ & - & - \\
\hline
\end{tabular}

Data are expressed as proportion of $\alpha$-pinene concentration in the corresponding plant condition; $\alpha$-pinene was emitted at $5.06 \pm 0.74,0.73 \pm 0.14$, and $1.43 \pm 0.61 \mu \mathrm{g} \mathrm{mL}^{-1}$ by graft 'Hass'/'Mexicola', 'Hass'/'Zutano' and ungrafted 'Mexicola', respectively. Means sharing a letter, for each compound, do not differ significantly according to Tukey's test $(\mathrm{P}<0.05)$.

*Significant differences according Student's $t$-test $(\mathrm{P}<0.05)$. 
Mexican race. Higher amounts of aromatic aldehydes were released by 'Mexicola' shoots. The graft 'Hass'/'Mexicola' did not emit 3-ethyl-benzaldehyde although 'Hass'-shoots, grafted on 'Zutano', emitted significantly low amounts of 3-ethyl-benzaldehyde ( $\mathrm{t}=2.386 ; \mathrm{p}<0.044)$ in comparison to 'Mexicola' plants (Table 1 ). Therefore, the chemical profiles are different within avocado species as it in the monoterpenes, alkanes, phenylpropanoids and aldehydes biosynthesis, affected by the genotype rootstock in avocado plants.

Although, morphological and physiological parameters were not measured, 'Hass' shoots were vigorous and the emission of alkanes was stimulated when were grafted on 'Zutano' rootstock. Alkanes are major constituents of epicuticular waxes promoting drought tolerance, UV-radiation protection and defenses against insects and pathogens (Bernard et al., 2012; Bush and McInerney, 2013). Rootstocks can enhance tolerance to abiotic and biotic stressors, and its benefits has been studied several species as kiwifruit (Actinidia deliciosa), apple (Malus domestica), and pomegranate (Punica granatum) (Warschefsky et al., 2016). According to Warschefsky et al. (2016) many aspects of rootstock biology are at initial stages, including long-distance molecular signaling and the capacity of rootstocks to modulate interaction between plant and soil microbiomes.

\section{CONCLUSIONS}

Volatile profile released by grafted 'Hass' avocado plants was affected by both 'Mexicola' and 'Zutano' rootstocks. Grafted 'Hass' on 'Mexicola' emitted a wide variety of more monoterpenes than plants grafted on 'Zutano'. Estragole was only detected on ungrafted 'Mexicola' plants, 3-carene, (Z)- $\beta$-ocimene, 2-propyl-1-pentanol, R-limonene and (2E, 6E)-4,5dimethyl-2,6-octadiene were identified only in the volatile profile of 'Hass'/'Mexicola' plants. Undecane, 2,3-dimethylheptane and 3,4,5-trimethyl-heptane were collected from 'Hass'/'Zutano' plants.

\section{ACKNOWLEDGEMENTS}

We extend our gratitude to Instituto de Investigaciones Agropecuarias staff and Centro Regional de Investigación La Cruz, Región de Valparaíso, Chile.

\section{REFERENCES}

Arimura, G., Ozawa, R., and Maffei, M. 2011. Recent advances in plant early signaling in response to herbivory. International Journal of Molecular Sciences 12:3723-3739.

Becker, C., Desneux, N., Monticelli, L., Fernandez, X., Michel, T., and Lavoir, A.-V. 2015. Effects of abiotic factors on HIPVmediated interactions between plants and parasitoids. BioMed Research International 2015:ID342982.

Bernard, A., Domergue, F., Pascal, S., Jetter, R., Renne, C., Faure, J.-D., et al. 2012. Reconstitution of plant alkane biosynthesis in yeast demonstrates that Arabidopsis ECERIFERUM1 and ECERIFERUM3 are core components of a very-long-chain alkane synthesis complex. The Plant Cell 24:3106-3118. doi:10.1105/tpc.112.099796.

Bravo-Monzón, A.E., and Espinosa-García, F.J. 2008. Volatile emissions in Persea americana in response to the stem borer Copturus aguacatae attack. Allelopathy Journal 21:165.

Bush, R.T., and McInerney, F.A. 2013. Leaf wax $n$-alkane distributions in and across modern plants: Implications for paleoecology and chemotaxonomy. Geochimica et Cosmochimica Acta 117:161-179. doi:10.1016/j.gca.2013.04.016.

Ceballos, R., Fernández, N., Zúñiga, S., and Zapata, N. 2015. Electrophysiological and behavioral responses of pea weevil Bruchus pisorum L. (Coleóptera: Bruchidae) to volatiles collected from its host Pisum sativum L. Chilean Journal of Agricultural Research 75:202-209. doi:10.4067/s0718-58392015000200009.

Clavijo, A. 2016. Can plant - natural enemy communication withstand disruption by biotic and abiotic factors? Ecology and Evolution 6:8569-8582.

Colla, G., Rouphael, Y., Leonardi, C., and Bie, Z. 2010. Role of grafting in vegetable crops grown under saline conditions. Scientia Horticulturae 127:147-155. doi:10.1016/j.scienta.2010.08.004.

Cookson, S.J., Clemente Moreno, M.J., Hevin, C., Nyamba Mendome, L.Z., Delrot, S., Trossat-Magnin, C., et al. 2013. Graft union formation in grapevine induces transcriptional changes related to cell wall modification, wounding, hormone signalling, and secondary metabolism. Journal of Experimental Botany 64:2997-3008. doi:10.1093/jxb/ert144.

García-Rodríguez, M.Y., Torres-Gurrola, G., Meléndez-González, C., and Espinosa-García, F.J. 2016. Phenotypic variations in the foliar chemical profile of Persea americana Mill. cv. Hass. Chemistry and Biodiversity 13:1767-1775. doi:10.1002/cbdv.201600169. 
Gols, R. 2014. Direct and indirect chemical defences against insects in a multitrophic framework. Plant, Cell and Environment 37:1741-1752.

Hare, J. 2010. Ontogeny and season constrain the production of herbivore-inducible plant volatiles in the field. Journal of Chemical Ecology 36:1363-1374.

Hare, J., and Sun, J. 2011. Production of herbivore-induced plant volatiles is constrained seasonally in the field but predation on herbivores is not. Journal of Chemical Ecology 37:430-442.

Heil, M. 2014. Herbivore-induced plant volatiles: targets, perception and unanswered questions. New Phytologist 204:297-306.

Holopainen, J.K., and Blande, J.D. 2013. Where do herbivore-induced plant volatiles go? Frontiers in Plant Science 4:185. doi:10.3389/fpls.2013.00185.

Jamwal, K., Bhattacharya, S., and Puri, S. 2018. Plant growth regulator mediated consequences of secondary metabolites in medicinal plants. Journal of Applied Research on Medicinal and Aromatic Plants 9:26-38. doi:10.1016/j.jarmap.2017.12.003.

Kegge, W., and Pierik, R. 2010. Biogenic volatile organic compounds and plant competition. Trends in Plant Science 15:126-132. doi:10.1016/j.tplants.2009.11.007.

Lordan, J., Fazio, G., Francescatto, P., and Robinson, T. 2017. Effects of apple (Malus xdomestica) rootstocks on scion performance and hormone concentration. Scientia Horticulturae 225:96-105. doi:10.1016/j.scienta.2017.06.050.

Loreto, F., Dicke, M., Schnitzler, J.P., and Turlings, T.C.J. 2014. Plant volatiles and the environment. Plant, Cell and Environment 37:1905-1908. doi:10.1111/pce.12369.

Lu, P.F., Wang, R., Wang, C.Z., Luo, Y.Q., and Qiao, H.L. 2015. Sexual differences in electrophysiological and behavioral responses of Cydia molesta to peach and pear volatiles. Entomologia Experimentalis et Applicata 157:279-290. doi:10.1111/eea.12362.

Martínez-Ballesta, M.C., Alcaraz-López, C., Muries, B., Mota-Cadenas, C., and Carvajal, M. 2010. Physiological aspects of rootstock-scion interactions. Scientia Horticulturae 127:112-118. doi:10.1016/j.scienta.2010.08.002.

Mithöfer, A., and Boland, W. 2012. Plant defense against herbivores: Chemical aspects. Annual Review of Plant Biology 63:431450. doi:10.1146/annurev-arplant-042110-103854.

Moreno-Medina, B.L., Casierra-Posada, F., and Cutler, J. 2018. Phytochemical composition and potential use of Rubus species. Gesunde Pflanzen 70:65-74. doi:10.1007/s10343-018-0416-1.

Proffit, M., Birgersson, G., Bengtsson, M., Reis, R., Witzgall, P., and Lima, E. 2011. Attraction and oviposition of Tuta absoluta females in response to tomato leaf volatiles. Journal of Chemical Ecology 37:565-574.

Reeksting, B.J., Taylor, N.J., and van den Berg, N. 2014. Flooding and Phytophthora cinnamomi: Effects on photosynthesis and chlorophyll fluorescence in shoots of non-grafted Persea americana (Mill.) rootstocks differing in tolerance to Phytophthora root rot. South African Journal of Botany 95:40-53. doi:10.1016/j.sajb.2014.08.004.

Rincón-Hernández, C., Sánchez, J., y Espinosa-García, F. 2011. Caracterización química foliar de los árboles de aguacate criollo (Persea americana var. drymifolia) en los bancos de germoplasma de Michoacán, México. Revista Fitotecnia Mexicana 82:395-412.

Rioja, T., Ceballos, R., and Holuigue, L. 2018. Herbivore-induced plant volatiles emitted from avocado shoots infested by Oligonychus yothersi (Acari: Tetranychidae) increases the attraction of micro-coleopterans. Chilean Journal of Agricultural Research 78(3):447-458.

Rioja, T., Ceballos, R., Holuigue, L., and Vargas, R. 2016. Different population densities and continuous feeding by Oligonychus yothersi (McGregor) (Acari: Tetranychidae) affect the emissions of herbivore-induced plant volatiles on avocado (Persea americana Mill. cv. Hass) shoots under semi-field conditions. International Journal of Acarology 42:310-318.

Sabelis, M.W., Janssen, A., and Takabayashi, J. 2011. Can plants evolve stable alliances with the enemies' enemies? Journal of Plant Interactions 6:71-75. doi:10.1080/17429145.2011.556262.

Schwarz, D., Rouphael, Y., Colla, G., and Venema, J.H. 2010. Grafting as a tool to improve tolerance of vegetables to abiotic stresses: Thermal stress, water stress and organic pollutants. Scientia Horticulturae 127:162-171. doi:10.1016/j.scienta.2010.09.016.

Torres-Gurrola, G., Delgado-Lamas, G., and Espinosa-García, F.J. 2011. The foliar chemical profile of criollo avocado, Persea americana var. drymifolia (Lauraceae), and its relationship with the incidence of a gall-forming insect, Trioza anceps (Triozidae). Biochemical Systematics and Ecology 39:102-111. doi:10.1016/j.bse.2011.01.011.

Trinchera, A., Pandozy, G., Rinaldi, S., Crinò, P., Temperini, O., and Rea, E. 2013. Graft union formation in artichoke grafting onto wild and cultivated cardoon: An anatomical study. Journal of Plant Physiology 170:1569-1578. doi:10.1016/j.jplph.2013.06.018.

Ueda, H., Kikuta, Y., and Matsuda, K. 2012. Plant communication. Plant Signaling and Behavior 7:222-226. doi:10.4161/psb.18765.

Wang, J., Jiang, L., and Wu, R. 2016. Plant grafting: how genetic exchange promotes vascular reconnection. New Phytologist 214:56-65. doi:10.1111/nph.14383.

Warschefsky, E.J., Klein, L.L., Frank, M.H., Chitwood, D.H., Londo, J.P., von Wettberg, E.J.B., et al. 2016. Rootstocks: Diversity, domestication, and impacts on shoot phenotypes. Trends in Plant Science 21:418-437. doi:10.1016/j.tplants.2015.11.008. 